\title{
A NEW SPEGIES OF STICHOTHAMNION (RHODOPHYTA) FROM THE WEST INDIES
}

\author{
M. VROMAN \\ (Department of Botany, Free University, Amsterdam) \\ (received November 2nd, 1965)
}

The genus Stichothamnion (Rhodomelaceae) was described by BøRGESEN in 1930, on the basis of material from the north western coast of Gran Canaria (Canary Islands).

During our investigation of marine algae collected from the Netherlands Antilles it appeared that on St. Eustatius (Lesser Antilles) an unknown species was gathered, that also has to be placed in the genus Stichothamnion. This material was of sufficient quality to allow a complete description of the species.

Stichothamnion antillarum nov. spec.

Frons dorsiventralis, 4-9 $\mathrm{mm}$ alta.

Surculus $85-110 \mu$ latus, articulis $50-145 \mu$ longis, ca 10 cellulas pericentrales continentibus.

Rhizoidea ex cellulis pericentralibus orta, usque ad $400 \mu$ longa, 17-23 $\mu$ lata, 1-4 ex eodem articulo.

Ramuli erecti plus minusve subdichotome divisi, in parte basali et in parte media $80-115 \mu$ lati, articulis $55-110 \mu$ longis.

In superiori parte ramulorum trichoblasta simplicia, ca 19-27 $\mu$ lata, $310-1200 \mu$ longa.

Tetrasporangia $42-50 \mu$ lata, $38-42 \mu$ longa. .

Corpuscula antheridiorum subcylindrica, pedicellata, $190-260 \mu$ longa, $40-60 \mu$ lata.

Cystocarpia urceolata, 327-378 $\mu$ longa, 258-327 $\mu$ lata.

Type: West Indies, St. Eustatius, Back off Bay, on andesitic rocks, $21 \mathrm{~V} 1958$.

leg. M. Vroman (herbarium of the Free University, Amsterdam; isotype Rijksherbarium, Leiden).

On the southern coast of St. Eustatius a remarkable geological formation, known as Sugarloaf and White Wall, is found, resting in a sloping position against the southern incline of the Quill vulcano. At the foot of this formation, over a length of about $100 \mathrm{~m}$, the coastal line is formed by small boulders of andesitic origin. (Fig. 1). Normally the coast is strongly exposed to the prevaling eastern winds.

In the littoral zone, constantly washed by the waves, we find a close, mosslike algal growth in which the following species could be recognized: 
Polysiphonia ferulacea, Lophosiphonia cristata, Spyridia aculeata, Laurencia papillosa, Laurencia microcladia, Dictyota ciliolata, Dictyota dentata, Herposiphonia tenella, Padina vickersiae and Pocockiella variegata. In this vegetation Stichothamnion antillarum is found.

Its growing place shows a remarkable likeness to that of Stichothamnion cymatophilum on the Canary Islands. Macroscopically it is difficult to distinguish Stichothamnion antillarum from Lophosiphonia cristata and Polysiphonia ferulacea, both species that are very common in this place.

Like Lophosiphonia cristata Stichothamnion antillarum shows a marked dorsiventrality. The plant has a creeping rhizome-like stem, fixed to the substrate by numerous small rhizoids. From the dorsal side 4-9 $\mathrm{mm}$ tall branchlets are formed, while the rhizoids are formed along the ventral side of the rhizome, $1-4$ rhizoids from each segment. These rhizoids originate from the pericentral cells and have a length of up to $400 \mu$, but they are usually somewhat shorter (Fig. 4). At their ends small hapters are formed, by which they are fixed to the boulders. The diameter of the rhizoids is $17-23 \mu$. The walls are very thick and the lumen therefore is usually very narrow, $2-4 \mu$.

The rhizome grows in length by means of a large apical cell, from the basal end of which narrow flat cells are cut off. These divide in a central cell and about 10 pericentral cells. The fullgrown rhizome has a diameter of about 85-110 $\mu$. The length of the segments is variable, $50-145 \mu$.

The branching of the rhizome takes place in the same way as described by BørGesen (1930) for Stichothamnion cymatophilum.

The apical cell is divided by a curved wall into a small disc like cell, which forms a new apical cell, and a larger cell below (Fig. 2a, b). Both cells function as an apical cell and from their basal end narrow disc like cells are cut off, which divide into central and pericentral cells. The filaments, formed in this way, divergate, and thus two branches are formed.

On the upper side of the rhizome the erect branches develop, usually after every 4-6 segments. They are endogenous in origin and grow, just like the rhizome, by means of a large, conical apical cell. The diameter of the erect branches is approximately the same over their whole length, 80-115 $\mu$, and they are not narrowed at their base (Fig. 3). The segments have a length of 55-110 $\mu$ and possess 10-11 pericentral cells (Fig. 2j).

After the branchlets have reached some length they form trichoblasts. From the apical cell a segment is cut off by an oblique curved wall. Then a second wall is formed, almost perpendicular to the first. In this way a new apical cell is formed from which the trichoblast develops (Fig. 2e-h). First a number of short cells is formed; afterwards these cells lengthen and become colourless (Fig. 7). The trichoblasts are placed in an irregular spiral. In the older parts of the plant the trichoblasts die away. The trichoblasts can reach a length of $310-1200 \mu$, the diameter at their base is 19-27 $\mu$; towards 
M. VROMAN: A new species of Stichothamnion (Rhodophyta) from the West Indies

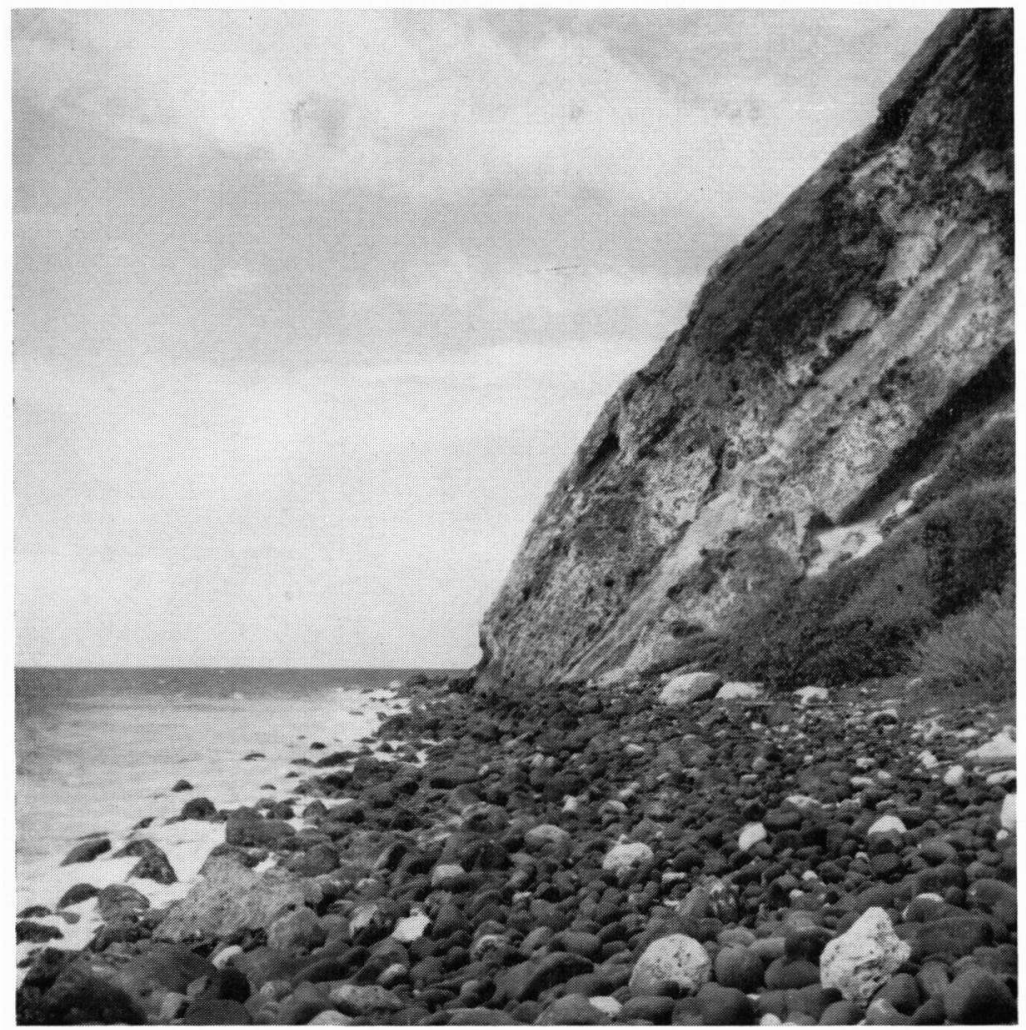

Fig. 1. St. Eustatius, growing place of Stichothamnion antillarum nov. spec. at the foot of Sugar Loaf and White Wall. 


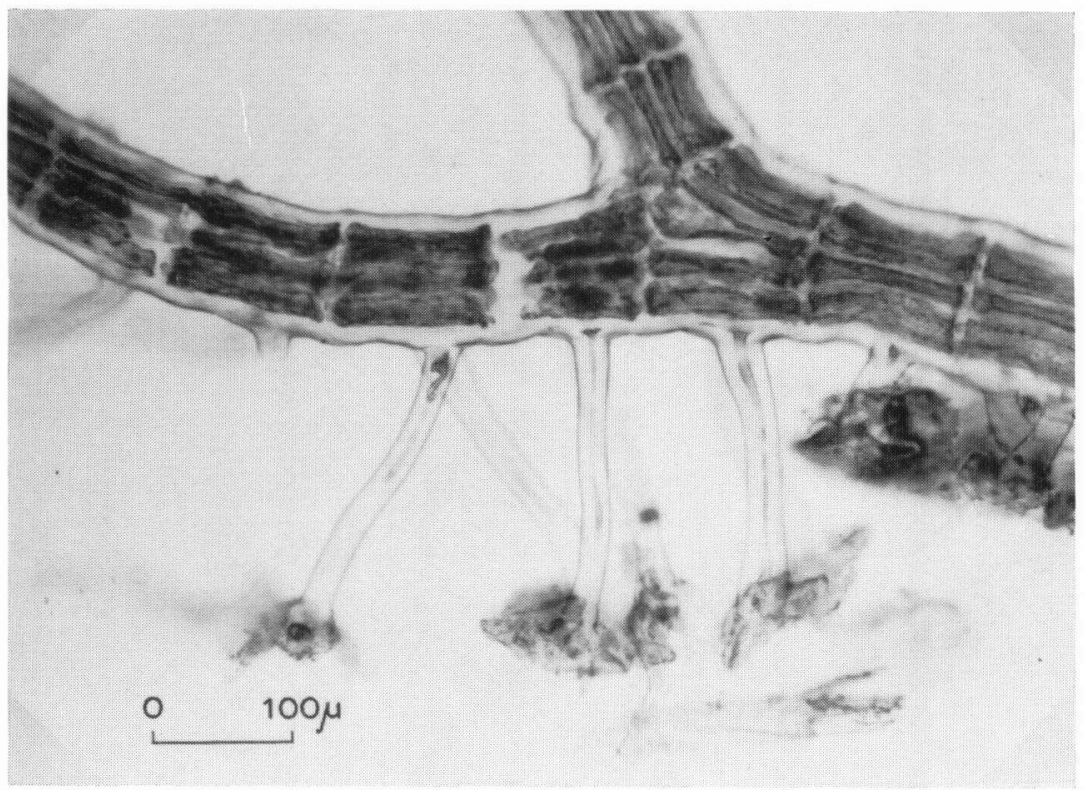

Fig. 4. Stichothamnion antillarum nov. spec., part of a creeping stem with rhizoids.

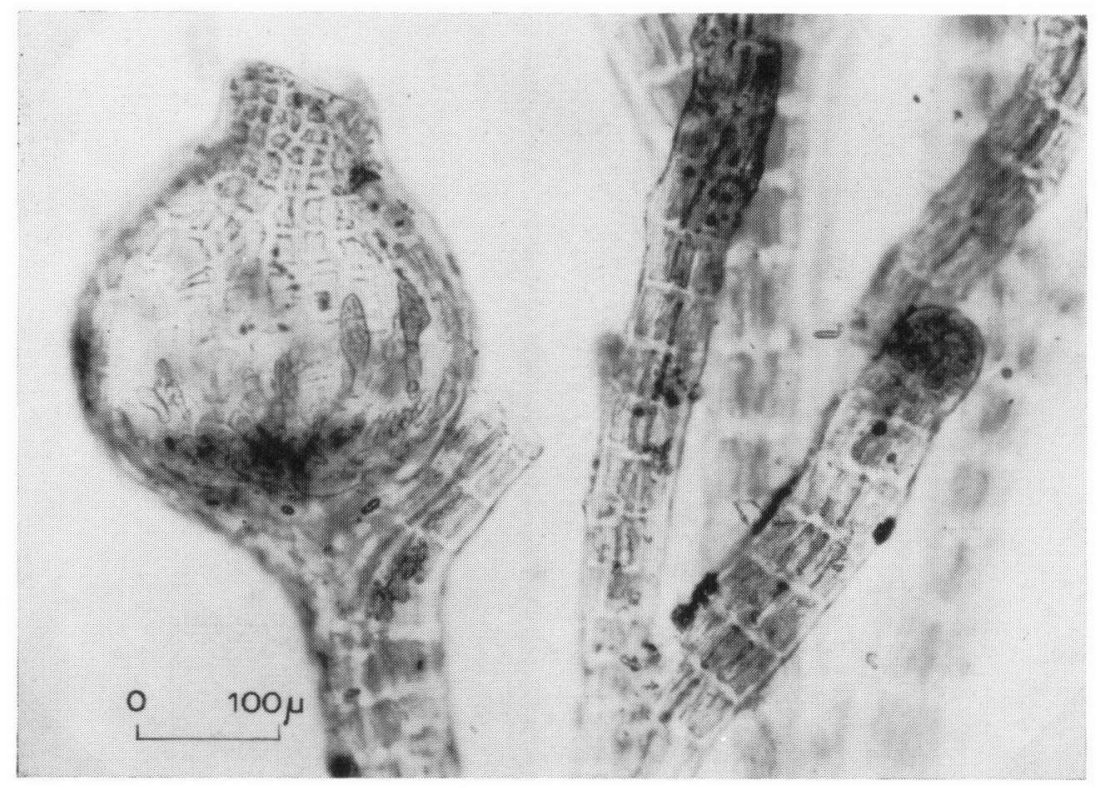

Fig. 5. Stichothamnion antillarum nov. spec., female plant with cystocarps.

PLATE II 

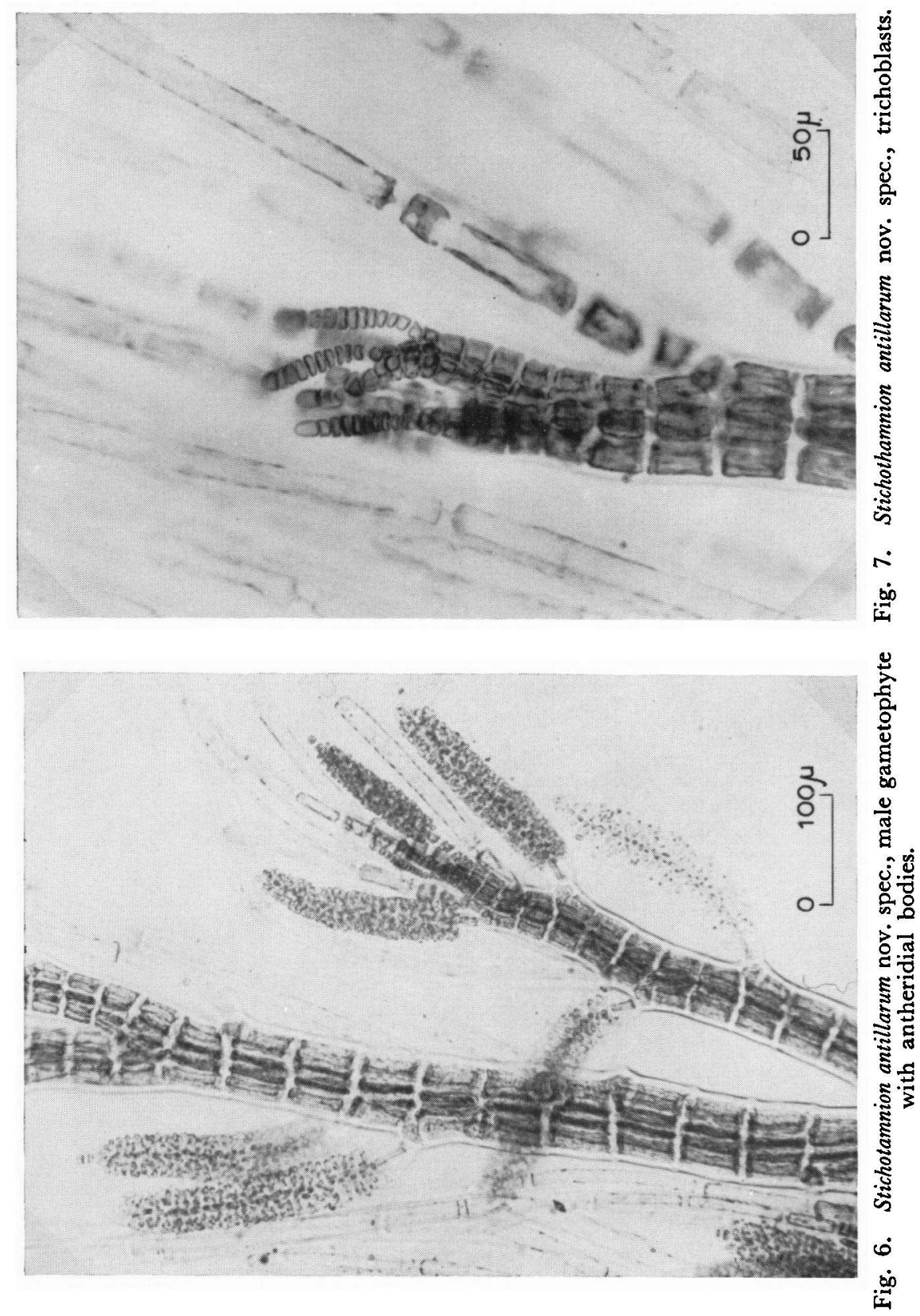

PLATE III 


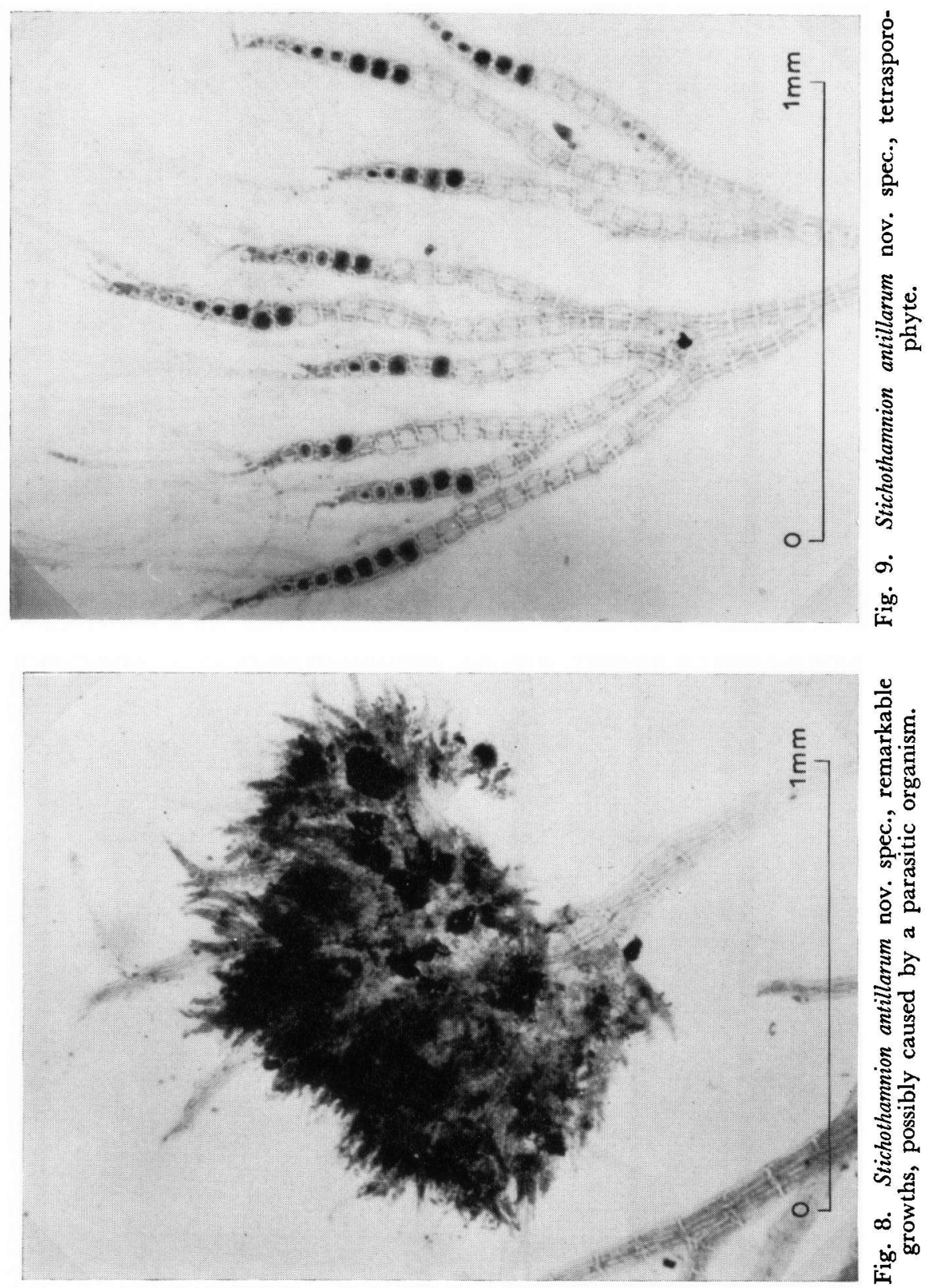

PLATE IV 
their tips the diameter is smaller, about $11.5 \mu$. The cells of the fullgrown trichoblast have a great length, to about $210 \mu$.

The greater part of the material from St. Eustatius consists of tetrasporophytes, but male and female plants were also found. The length of the erect branches varies from 4-9 $\mathrm{mm}$. There are no differences in length between the tetrasporophytes and the gametophytes. The branching of the fullgrown plants is subdichotomous.

The tetrasporangia are formed in an irregular spiral in the upper part of the erect branches, one in each segment (Fig. 9). The sporangia have a length of about $42 \mu$; usually they are somewhat broader than long, $42-50 \mu$.
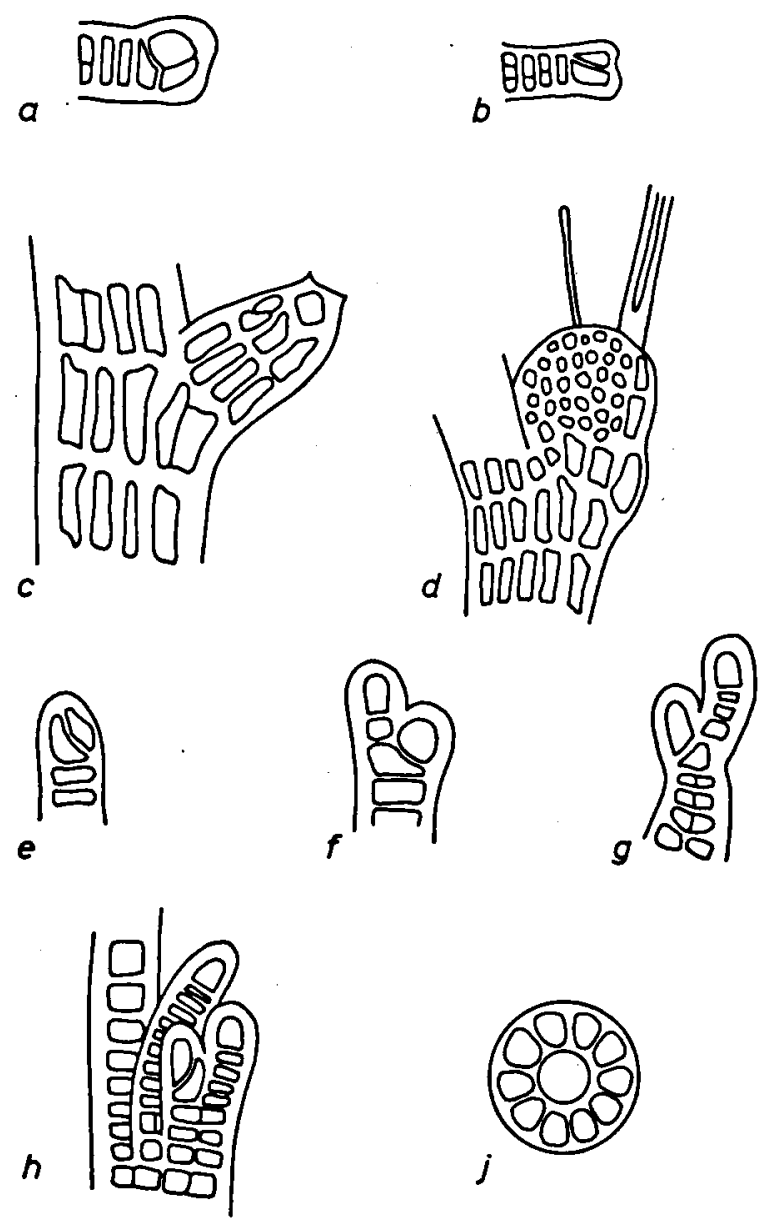

Fig. 2. Stichothamnion antillarum nov. spec. a-b, branching of the rhizome; $c$, development of the procarp; $d$, young cystocarp; $\mathrm{e}-\mathrm{h}$, development of trichoblasts; $j$, tranverse section of an erect branch of the thallus. 
The antheridial bodies are formed by the trichoblasts of the male plants (Fig. 6). The two lowermost cells of the trichoblast remain sterile, and form the stalk of the antheridial body. At the tip one or two cells also can remain sterile. The young trichoblast, which is going to form the antheridial body, consists in the beginning, just like a sterile trichoblast, of a row of short cells. Very soon these

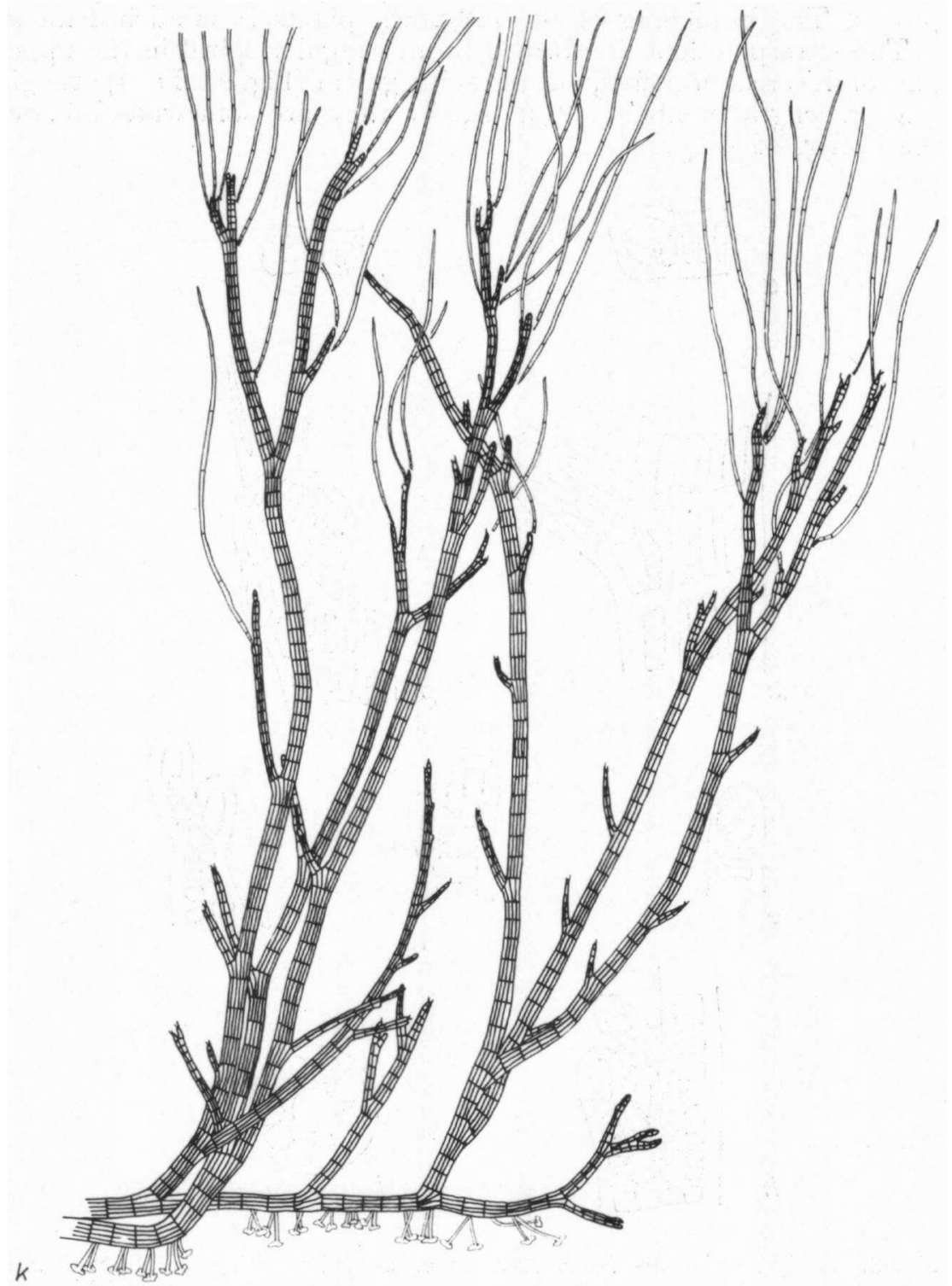

Fig. 3. Stichothamnion antillarum nov. spec. part of a young sterile plant. 
cells are divided into central and pericentral cells, from the latter the antheridia are formed after several divisions. The central cells form a percurrent row through the antheridial body. The fully developed antheridial bodies are subcylindrical in shape, 190-260 $\mu$ long and $40-60 \mu$ in diameter.

On the male gametophytes, and also on one or two tetrasporophytes several remarkable growths were found, not unlike the formations caused by parasitic microorganisms in the higher plants (Fig. 8). Their diameter is about $1 \mathrm{~mm}$.

The growths are formed by a very close branching of Stichothamnion. Trichoblasts remain very short or are not formed at all. I did not find the cause for these growths. A fungus is possibly the reason.

The female plants, of which only two were found, are subdichotomously branched and the cystocarps are formed on the trichoblasts in the upper part of the plants. The two lowermost segments of a trichoblast become plurisiphonous, the uppermost of these two segments forms the procarp (Fig. 2c, d). During the development of the cystocarp the sterile part of the trichoblast drops off. When mature the cystocarp is urceolate, with a rather long neck in which an ostiole is formed (Fig. 5). From 5 ripe cystocarps the length varied between 327-378 $\mu$, their diameter between 258-327 $\mu$.

The carpospores are variable in form, oval to irregular.

From the description given above it is clear that the plant from St. Eustatius belongs to the genus Stichothamnion.

The organisation of the vegetative plant and the formation of the reproductive organs show a marked similarity to that of Stichothamnion cymatophilum, as described by BøRGesen (1930). But there are also several distinct differences. The measurements of the material from St. Eustatius are larger than from Stichothamnion cymatophilum and also the form and insertion of the young erect branches is quite different. For these reasons it seems justified to distinguish a new species, which we have named Stichothamnion antillarum.

\section{AGKNOWLEDGMENTS}

The author is highly indebted to Mr. H. Cook, M.S.A., for correcting the English text, to Dr. C. van den Hoek and Mrs. van den Hoek for their help with the latin diagnosis, to Mr. G. van Groeningen for preparing the microphotographs and to Mr. G. W. H. van den Berg for drawing the figures.

\section{REFERENCES}

Børgesen, F. 1930. Marine algae from the Canary Islands, especially from Teneriffe and Gran Canaria. III. Rhodophyceae, part III. Ceramiales. Kongel. Danske Vidensk. Selsk., Biol. Medd. 9: 118-131, fig. 49-55. Copenhagen.

Kylin, H. 1956. Die Gattungen der Rhodophyceen. Lund.

TAYLOR, W. R. 1960. Marine algae of the eastern tropical and subtropical coasts of the Americas. Ann Arbor. 